\title{
DICLE RINGING STATION (SE TURKEY) - RINGING RESULTS AND SEASONAL BIRD MIGRATION DYNAMICS IN 2003-2005
}

\author{
Monika Filar, Murat Biricik
}

\begin{abstract}
Filar M., Biricik M. 2006. Dicle Ringing Station (SE Turkey) - ringing results and seasonal bird migration dynamics in 2003-2005. Ring 28, 2: 135-145.

Dicle Ringing Station is a field station in the campus of Dicle University, Diyarbakır (SE Turkey), and has been working since 2003. From that year it also belongs to the SEEN organization (SE European Bird Migration Network). The paper includes information collected during three autumn and one spring seasons. Totally, 5393 birds were ringed. Detailed information about study site and ringing results are reported in the paper.
\end{abstract}

M. Filar, Bird Migration Research Station, University of Gdańsk, Przebendowo, PL-84-210 Choczewo, Poland, E-mail: biomf@univ.gda.pl; M. Biricik, University of Dicle, Faculty of Science and Art, Department of Biology, TR-21280 Diyarbakır, Turkey, E-mail: mbiricik@dicle.edu.tr

Publication appointed to the SE European Bird Migration Network papers

Key words: ringing station, Turkey, migration, seasonal dynamics

\section{STUDY AREA AND METHODS}

Diyarbakır, with about half a million population, is one of the biggest cities in SE Anatolia. Originally, the main land type in the region is a lowland steppe with some semi-desert areas in southern part of the region, especially near the Syrian border of the country. However, the region is considered as the main agricultural ground of Turkey now, after the irrigation by means of several recently constructed big dams. The only elevation, except for the SE Taurus Mountain chains, which are almost boundaries to other geographical regions of Turkey, is Karacadağ - an ancient volcano with its peak at $1919 \mathrm{~m}$ a.s.l. The historic city of Diyarbakır is situated on a basalt plateau, which is originally formed by lava of Karacadağ. Just adjacent to eastern boundaries of the large rocky area the Tigris flows, one of two main Middle-East rivers. The fertile land between the Tigris and Euphrates is called Mesopotamia. 
The campus of Dicle University is situated on the opposite side of the river, at the distance of about $1 \mathrm{~km}$ from the city $\left(37^{\circ} 54^{\prime} \mathrm{N}, 40^{\circ} 15^{\prime} \mathrm{E}\right)$. Location of the study area is shown on a map of Turkey in Figure 1. Some of nearly natural habitats are still to be found in the campus area, for example shrub lands at the river bank. The Dicle Ringing Station was established near the river, inside a low willow grove with some other bushes and reeds (Plate 1 and 2). About 60 plant species are known in the area and surrounding sites. Dense woodland consisting mainly of willows Salix acmophylla dominates along the river bed and on the shores of the streams that flow into the river. Ranunculus species, Daisy (Bellis perennis), Common Fleabane (Pulicaria dysenterica), Mugwort (Artemisia vulgaris), Plantago species and Cogongrass (Imperata cylindrical) are the most common plants on the shore as well as in the marshes. Oriental Clematis (Clematis orientalis), Stranglewort (Cynanchum acutum), Sophora alopecuroides and Licorice (Glycyrrhiza glabra) are to be mentioned as abundant trees and bushes. Chaste Tree (Vitex agnus-cactus) and also Rubus sanctus build scrubland patches. Common Reed (Phraghmites communis) and Southern Cat-Tail (Typha domingensis), also Galingale (Cyperus longus), Glabrous Cyperus (Cyperus glaber), Roundhead Bulrush (Scirpoides holoschoenus) and False Fox-Sedge (Carex otrubae) dominate in the reedbeds around the ponds and marshes adjacent to the river. In the surrounding area, Threelobe Beggarticks (Bidens tripartite), Blue Fleabane (Erigeron acer), Epilobium sp., and bushy plants like Smyrna Tamarisk (Tamarix smrynensis), are quite common. Watercress (Nasturtium officinale), Fool's Watercress (Apium nodiflorum), Common Duckweed (Lemna minor) are the plants found in the water.

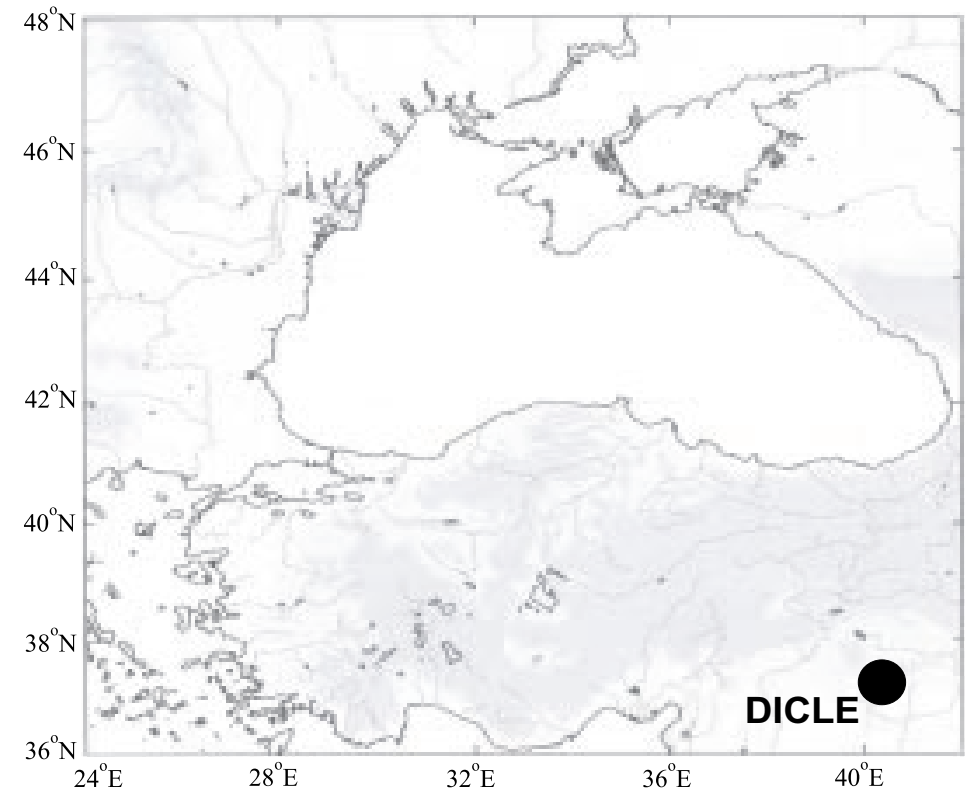

Fig. 1. The Dicle Ringing Station in Turkey 

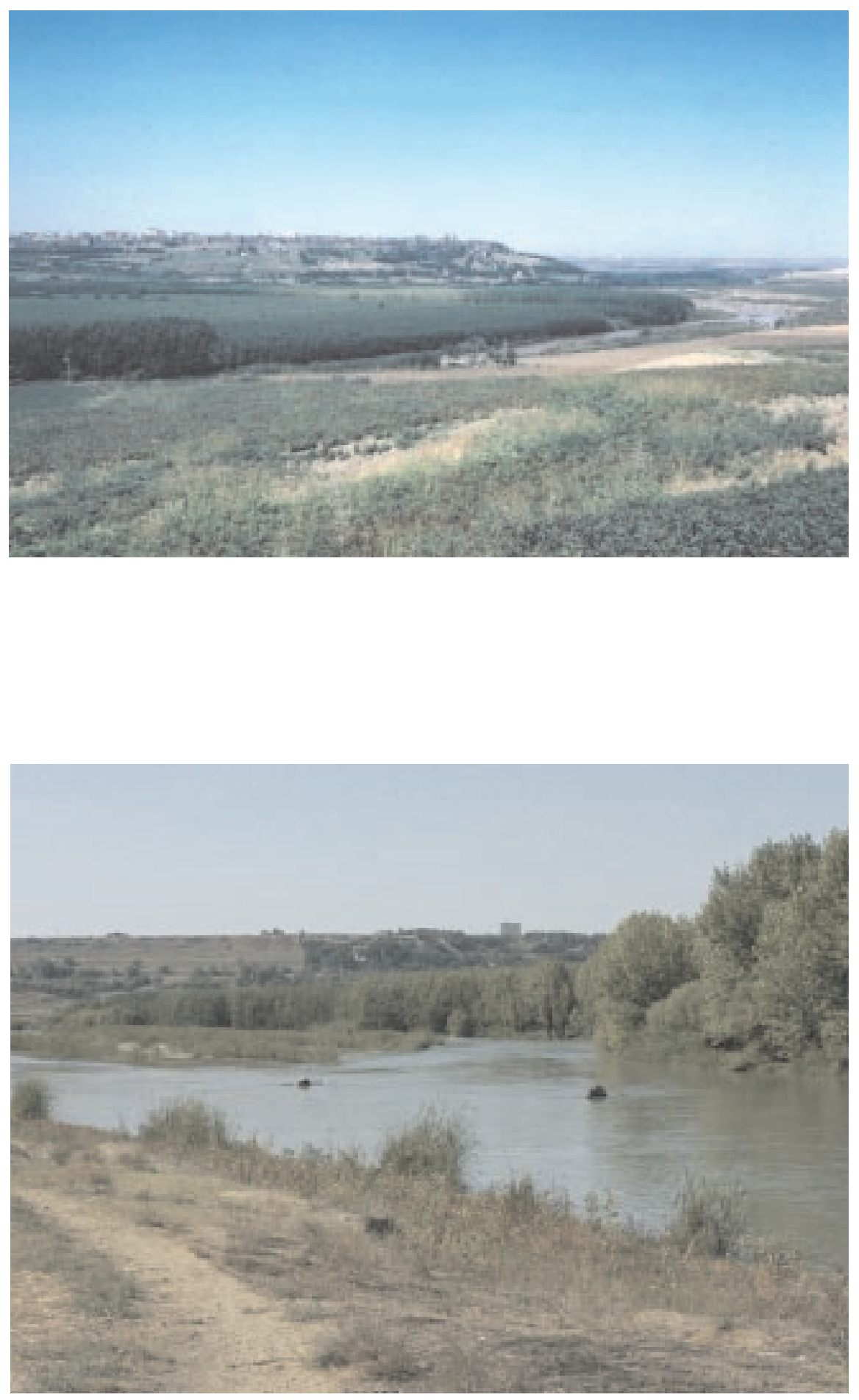

Plate 1. Biotopes characteristics of the Dicle Ringing Station site (Photo by R. Lasecki) 

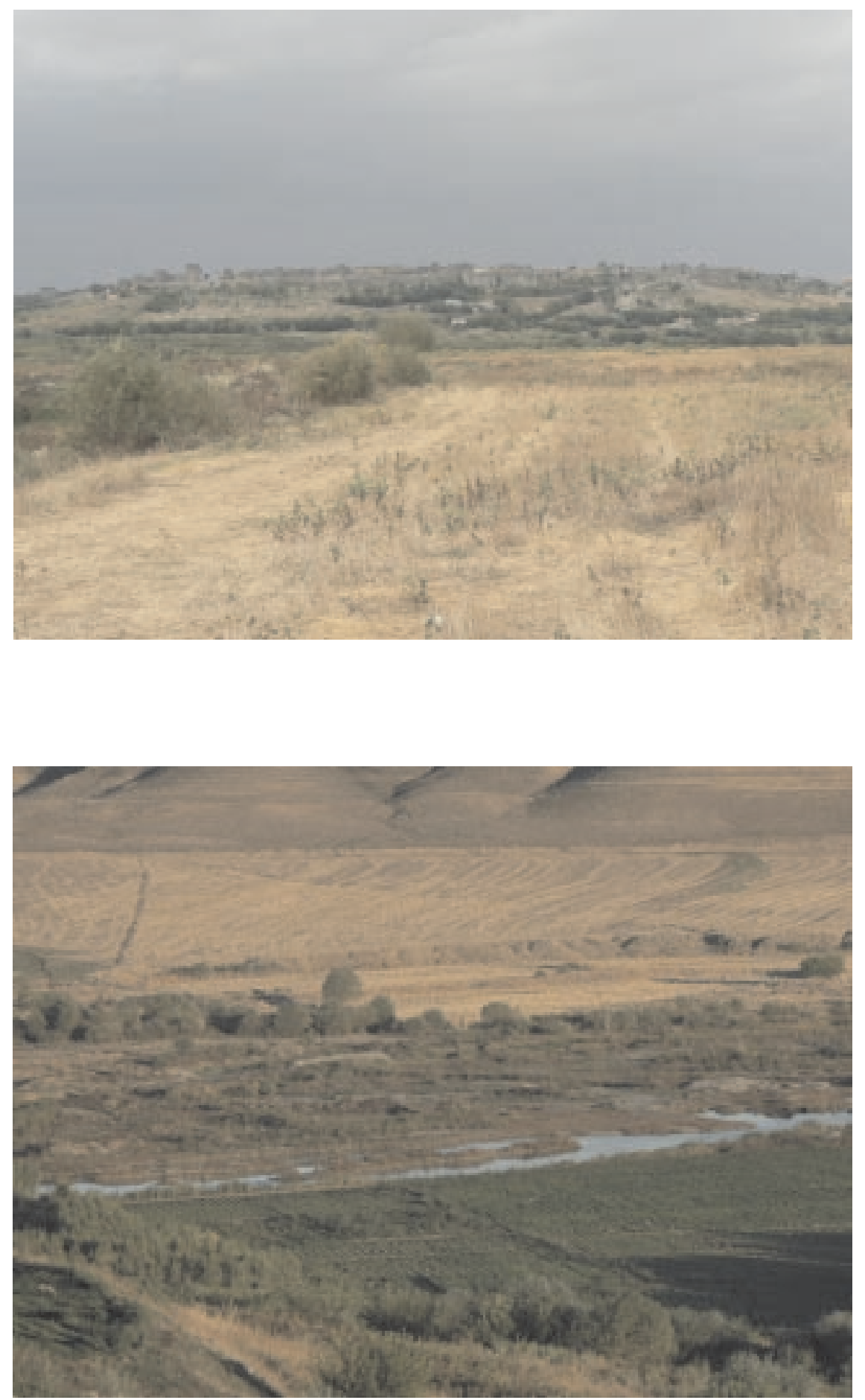

Plate 2. Biotopes characteristics of the Dicle Ringing Station site (Photo by R. Lasecki) 
Birds were caught in mist-nets and sometimes in special traps for water birds. After being caught, birds were determined for species, age and sex (if it was possible), scored for fat deposit, measured (tail, wing length and sometimes special measurements like tarsus in owls or notch in Acrocephalus warblers) and weighed. All methods were applied according to SEEN standards described in a book by Busse (2000). Some night migrants were also tested for directional preferences with Busse's cage (Busse 1995, 2000).

\section{RESULTS}

Time of work in the Dicle Ringing Station was different in each autumn season. In 2003 it was 23 Sep.-7 Oct., in $2004-8$ Sep.-28 Oct. and in $2005-1$ Sep.-22 Oct. Spring work lasted from 31 March to 24 April 2004. Totally, 5392 birds from 80 species were caught during three autumn seasons in 2003-2005 and one spring season in 2004 (Table 1). In 2003, totally 697 birds were caught, dominant species being the Bluethroat (Luscinia svecica) - 230 indiv., Barn Swallow (Hirundo rustica) - 107 indiv. and Reed Warbler (Acrocephalus scirpaceus) - 68 indiv. In autumn of 2004, totally 1567 birds were caught, among which the three most common species were: the Chiffchaff (Phylloscopus collybita) - 473 indiv., Bluethroat - 176 indiv. and Redstart (Phoenicurus phoenicurus) - 144 indiv. In 2005 we obtained the total number of 1092 caught birds, with the Chiffchaff (356 indiv.), Redstart (125 indiv.) and Bluethroat (95 indiv.) as dominant species. There was only one spring work at the station, but the results seem to be promising: 2036 birds were caught during about one-month work. The most numerous species were: the Willow Warbler (Phylloscopus trochilus) with total number of 785 caught individuals, Barn Swallow with 399 and Chiffchaff with 190 individuals.

Table 1

Number of birds caught in 2003-2005

\begin{tabular}{|c|c|c|c|c|c|}
\hline \multirow{2}{*}{ Scientific name } & \multirow{2}{*}{$\begin{array}{c}\text { Spring } \\
2004 \\
\end{array}$} & \multicolumn{3}{|c|}{ Autumn } & \multirow{2}{*}{ Tota } \\
\hline & & 2003 & 2004 & 2005 & \\
\hline Accipiter brevipes & 0 & 0 & 0 & 4 & 4 \\
\hline Accipiter nissus & 3 & 0 & 6 & 5 & 14 \\
\hline Acrocephalus arundinaceus & 20 & 5 & 8 & 8 & 41 \\
\hline Acrocephalus dumetorum & 1 & 0 & 0 & 0 & 1 \\
\hline Acrocephalus melanopogon & 1 & 0 & 0 & 0 & $\mathbf{1}$ \\
\hline Acrocephalus schoenobaenus & 16 & 2 & 2 & 3 & 23 \\
\hline Acrocephalus scirpaceus & 9 & 68 & 112 & 94 & 283 \\
\hline Acrocephalus palustris & 0 & 12 & 6 & 26 & 44 \\
\hline Alcedo attis & 11 & 5 & 36 & 32 & 84 \\
\hline Anthus trivialis & 1 & 8 & 5 & 8 & 22 \\
\hline Asio otus & 0 & 0 & 1 & 5 & 6 \\
\hline Buteo buteo & 0 & 0 & 0 & 1 & 1 \\
\hline Caprimulgus europaeus & 6 & 3 & 4 & 14 & 27 \\
\hline
\end{tabular}




\begin{tabular}{|c|c|c|c|c|c|}
\hline \multirow{2}{*}{ Scientific name } & \multirow{2}{*}{$\begin{array}{c}\text { Spring } \\
2004\end{array}$} & \multicolumn{3}{|c|}{ Autumn } & \multirow{2}{*}{ Tota } \\
\hline & & 2003 & 2004 & 2005 & \\
\hline Carpodacus erythrinus & 0 & 0 & 3 & 1 & 4 \\
\hline Cettia cetti & 4 & 2 & 31 & 39 & 76 \\
\hline Crex crex & 1 & 0 & 0 & 0 & 1 \\
\hline Coturnix coturnix & 0 & 1 & 3 & 5 & 9 \\
\hline Cuculus canorus & 0 & 0 & 1 & 0 & 1 \\
\hline Dendrocopos syriacus & 0 & 0 & 1 & 0 & 1 \\
\hline Emberiza citrinella & 1 & 0 & 0 & 0 & 1 \\
\hline Emberiza hortulana & 0 & 0 & 1 & 0 & 1 \\
\hline Emberiza schoeniclus & 1 & 0 & 1 & 0 & 2 \\
\hline Erithacus rubecula & 5 & 0 & 43 & 4 & 52 \\
\hline Falco columbarius & 0 & 0 & 0 & 1 & 1 \\
\hline Falco subbuteo & 0 & 0 & 0 & 1 & 1 \\
\hline Ficedula hypoleuca & 1 & 0 & 0 & 0 & 1 \\
\hline Ficedula semitorquata & 2 & 0 & 0 & 0 & 2 \\
\hline Fringilla coelebs & 1 & 0 & 7 & 1 & 9 \\
\hline Gallinula chloropus & 0 & 0 & 1 & 6 & 7 \\
\hline Gallinago gallinago & 0 & 0 & 3 & 0 & 3 \\
\hline Hirundo rustica & 399 & 107 & 5 & 19 & 537 \\
\hline Irania gutturalis & 7 & 0 & 0 & 0 & 7 \\
\hline Ixobrychus minutus & 5 & 0 & 0 & 5 & 10 \\
\hline Jynx torguilla & 5 & 6 & 9 & 9 & 29 \\
\hline Lanius collurio & 61 & 23 & 50 & 40 & 174 \\
\hline Lanius senator & 11 & 0 & 0 & 0 & 11 \\
\hline Locustella fluviatilis & 0 & 1 & 1 & 1 & 3 \\
\hline Locustella luscinioides & 8 & 3 & 7 & 4 & 22 \\
\hline Luscinia luscinia & 60 & 2 & 10 & 8 & 80 \\
\hline Luscinia megarynhos & 10 & 0 & 0 & 2 & 12 \\
\hline Luscinia svecica & 69 & 230 & 176 & 95 & 570 \\
\hline Lymnocryptes minimus & 0 & 0 & 0 & 4 & 4 \\
\hline Merops apiaster & 2 & 0 & 2 & 2 & 6 \\
\hline Muscicapa striata & 30 & 0 & 4 & 8 & 42 \\
\hline Oriolus oriolus & 0 & 0 & 1 & 3 & 4 \\
\hline Otus scops & 3 & 0 & 0 & 9 & 12 \\
\hline Otus brucei & 0 & 1 & 0 & 0 & 1 \\
\hline Parus caeruleus & 0 & 0 & 3 & 2 & 5 \\
\hline Parus major & 5 & 5 & 9 & 8 & 27 \\
\hline Passer domesticus & 10 & 5 & 15 & 3 & 33 \\
\hline Passer hispaniolensis & 0 & 4 & 2 & 2 & 8 \\
\hline Passer moabiticus & 83 & 1 & 1 & 3 & 88 \\
\hline Phoenicurus phoenicurus & 15 & 38 & 144 & 125 & 322 \\
\hline Phylloscopus collybita & 190 & 9 & 473 & 356 & 1028 \\
\hline Phylloscpous trochilus & 785 & 52 & 74 & 37 & 948 \\
\hline Phylloscopus ori & 1 & 0 & 0 & 0 & 1 \\
\hline Phylloscopus sibilatrix & 3 & 0 & 1 & 0 & 4 \\
\hline Pica pica & 3 & 4 & 7 & 5 & 19 \\
\hline Porzana porzana & 3 & 0 & 0 & 0 & 3 \\
\hline Porzana pusilla & 0 & 0 & 1 & 0 & 1 \\
\hline Prinia gracilis & 0 & 0 & 1 & 1 & 2 \\
\hline Prunella modularis & 0 & 0 & 1 & 0 & 1 \\
\hline
\end{tabular}




\begin{tabular}{|l|c|c|c|c|c|}
\hline \multirow{2}{*}{\multicolumn{1}{|c|}{ Scientific name }} & Spring & \multicolumn{3}{|c|}{ Autumn } & \multirow{2}{*}{ Total } \\
\cline { 2 - 5 } & 2004 & 2003 & 2004 & 2005 & \\
\hline Rallus aquaticus & 0 & 0 & 0 & 4 & $\mathbf{8}$ \\
Remiz pendulinus & 2 & 0 & 2 & 0 & $\mathbf{4}$ \\
Riparia riparia & 7 & 19 & 0 & 4 & $\mathbf{3 0}$ \\
Saxicola rubetra & 1 & 2 & 3 & 0 & $\mathbf{1 7}$ \\
Saxicola torquata & 0 & 3 & 6 & 2 & $\mathbf{1 1}$ \\
Sylvia melanocephala & 1 & 0 & 3 & 0 & $\mathbf{4}$ \\
Sylvia atricapilla & 15 & 14 & 78 & 20 & $\mathbf{1 2 7}$ \\
Sylvia borin & 10 & 30 & 54 & 22 & $\mathbf{1 1 6}$ \\
Sylvia communis & 103 & 25 & 111 & 18 & $\mathbf{2 5 7}$ \\
Sylvia curruca & 14 & 4 & 25 & 5 & $\mathbf{4 8}$ \\
Sylvia hortensis & 1 & 0 & 0 & 0 & $\mathbf{1}$ \\
Sylvia mystacea & 17 & 1 & 2 & 0 & $\mathbf{2 0}$ \\
Sylvia nisoria & 1 & 0 & 3 & 1 & $\mathbf{5}$ \\
Troglodytes troglodytes & 1 & 0 & 1 & 0 & $\mathbf{2}$ \\
Turdus merula & 2 & 0 & 2 & 0 & $\mathbf{4}$ \\
Turdus philomelos & 7 & 0 & 2 & 0 & $\mathbf{9}$ \\
Tyto alba & 0 & 0 & 0 & 4 & $\mathbf{4}$ \\
Upupa epops & 2 & 2 & 3 & 3 & $\mathbf{1 0}$ \\
\hline & $\mathbf{2 0 3 6}$ & $\mathbf{6 9 7}$ & $\mathbf{1 5 6 7}$ & $\mathbf{1 0 9 2}$ & $\mathbf{5 3 9 3}$ \\
\hline
\end{tabular}

Migration dynamics of the three most popular species in 2003 were quite concentrated, but the time of their migration peak varied among different species. In the Bluethroat its migration peak was at the beginning of October, the Barn Swallow had its peak at the end of September and the Reed Warbler - in the middle of catching season. In 2004 and 2005 the time of ringing work was longer than in 2003 (see migration dynamics in Figure 2), and probably that is the reason why the most numerous species composition was different (except for the Bluethroat). In 2004 the autumn migration dynamics of dominant species were as follows (Fig. 3): Chiffchaffs migrated in a quite concentrated way, with the migration peak at the end of October, while Bluethroats and Redstarts had rather extended dynamics of migration. Results obtained in 2005 were similar to the data from the previous year,
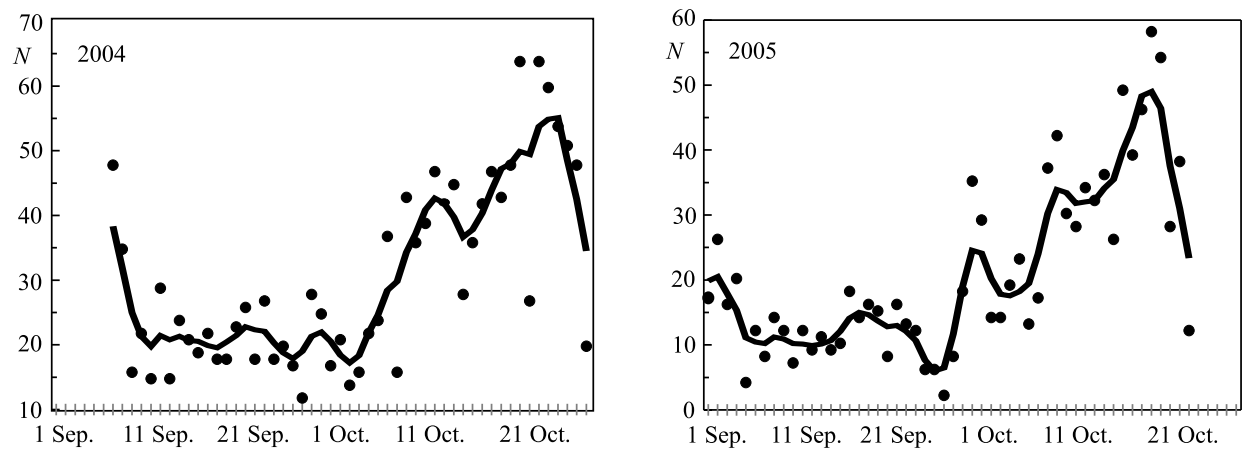

Fig. 2. Total ringing dynamics at the Dicle Ringing Station in autumns 2004 and 2005. Dots - daily ringing results, line - smoothed (by moving average) pattern. 

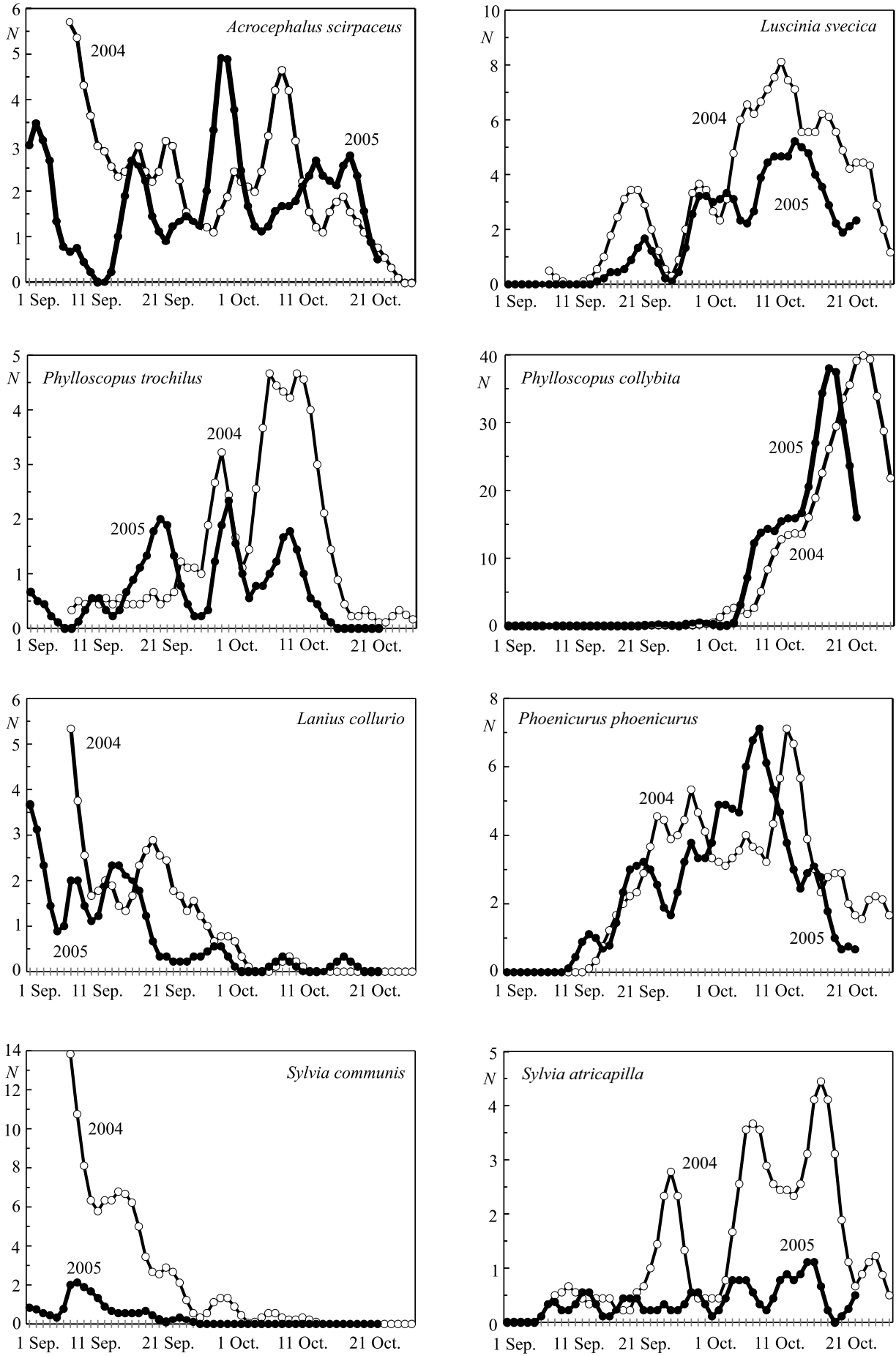

Fig. 3. Catching dynamics of the most numerous species at the Dicle Ringing Station in autumn (smoothed) 
however the total number of caught birds was lower than in previous year of about 500 birds, so the total individuals number of the most common species was also lower than in 2004. Migration of the Chiffchaff, which was the most numerous species, was concentrated and started in October, with a peak at the end of this month. The Redstart's migration was extended, started in the second half of September and lasted till the second half of October. In the Bluethroat the dynamics was also extended. Migration started in September but the catching results suggest that birds caught in September might have been the local ones. After those local birds we had four days without any Bluethroats and then migrants from further regions appeared.

Spring work in 2004 showed that the most intensive migration took place in the second half of the study period (Fig. 4). Both of the two dominant species: the Willow Warbler and Barn Swallow had their peaks of migration at the end of catching time (Fig. 5). Dynamics of the Willow Warbler migration concentrated at the end of April, as opposed to the Chiffchaff that had peak at the end of March. Migration of the Barn Swallow began on about 16 April and was not finished before the end of our work in the ringing station. Spring work should be continued longer to get information about the whole migration period.

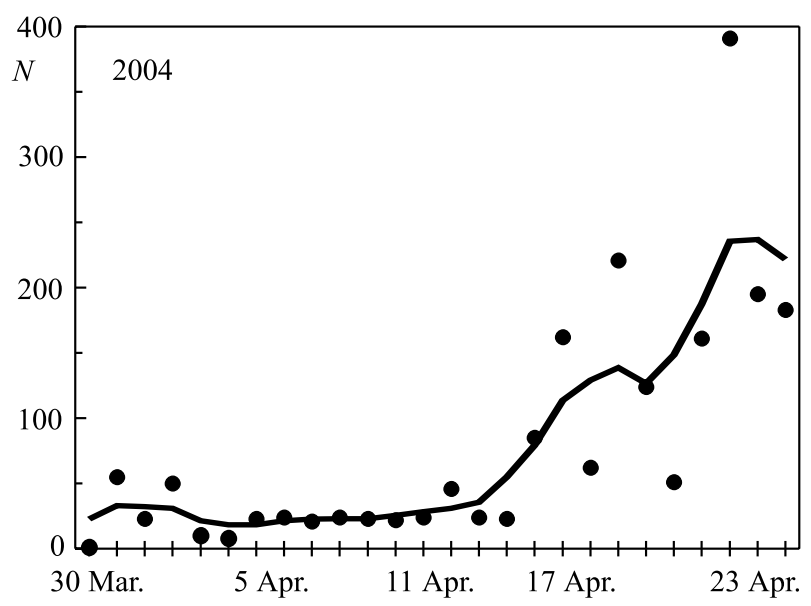

Fig. 4. Total ringing dynamics at the Dicle Ringing Station in spring 2004. Dots - daily ringing results, line - smoothed (by moving average) pattern

Another Turkish ringing station, Manyas, has got two places for ringing birds: Soltra and Milli Park. In both of those stations rather different species composition of dominating birds were observed. The most numerous species caught at the Dicle Ringing Station were also observed in Manyas Station, sometimes quite numerous, but usually not those dominant ones (Özgür Keşaplı in litt.).

The Cernek and Karaboğaz Ringing Stations are located in the north part of Turkey. Ringing activity at the Cernek Station showed that species caught there were quite similar to the species list from the Dicle Station, both in spring and 

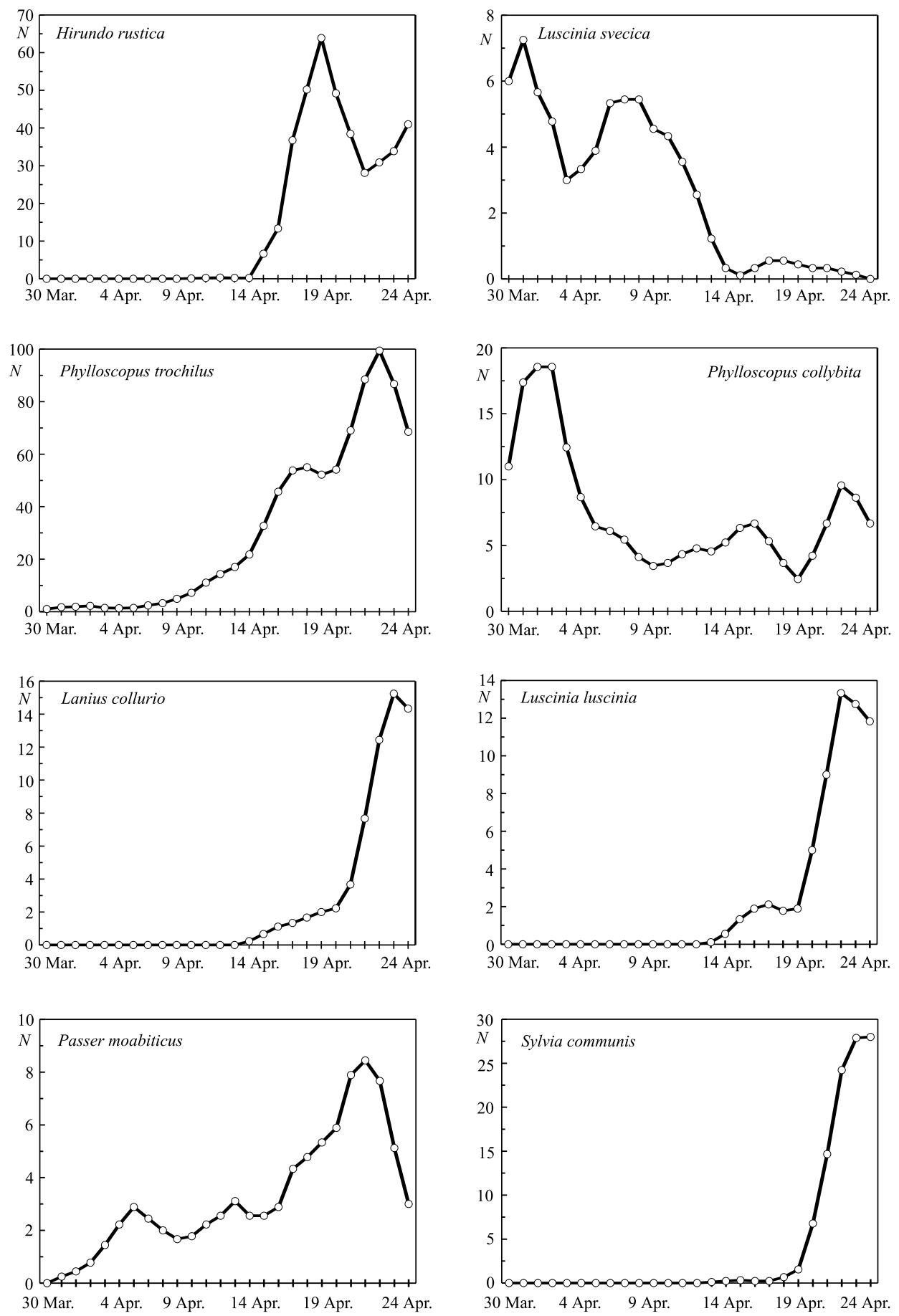

Fig. 5. Catching dynamics of the most numerous species at the Dicle Ringing Station in spring (smoothed) 
autumn seasons. It could be caused by rather similar biotope at these ringing places (reedbeds). However, at the Karaboğaz Station there was only one spring work in 2004 and the most numerous species were rather different, except for the Willow Warbler caught in a quite high number (Baris et al. 2005).

The Dicle Ringing Station could give us data about bird migration in still not well studied eastern part of Turkey. The obtained results seem to be promising. However, to get more detailed information further studies are necessary.

\section{ACKNOWLEDGEMENTS}

We would like to thank all colleagues from Bird Migration Research Station and all volunteers and students, especially the members of the Birdwatchers Club of Dicle University (DicleKuş) who helped us with fieldwork and with collecting the data. We are very grateful to ringing coordinators from Manyas Ringing Station for submitting their data. Special thanks to Prof. Selçuk Ertekin for botanical support.

This work is supported by the Research Fund of Dicle University (DÜAPK-02-FF-81).

\section{REFERENCES}

Baris S., Erciyas K., Gürsoy A., Özsemir C., Nowakowski J.K. 2005. Cernek - a new bird ringing station in Turkey. Ring 27, 1: 113-120.

Busse P. 1995. New technique of a field study of directional preferences of night passerine migrants. Ring 17, 1-2: 97-116.

Busse P. 2000. Bird Station Manual. Gdańsk. 